\title{
Racialized Burdens: Applying Racialized Organization Theory to the Administrative State
}

\author{
Victor Ray*, Pamela Herd ${ }^{+}$and Donald Moynihan ${ }^{+}$ \\ *Department of Sociology and Criminology, African American Studies \\ The University of Iowa \\ ${ }^{+}$McCourt School of Public Policy, Georgetown University
}

\section{Abstract}

This article develops the concept of racialized burdens as a means of examining the role of race in administrative practice. Racialized burdens are the experience of learning, compliance and psychological costs that serve as inequality reproducing mechanisms. To develop this concept, we examine administrative burdens in the US state from the theoretical perspective of racialized organizations. Using examples from attempts to access citizenship rights - via immigration, voting and the social safety net-we illustrate some key points. First, racialized burdens combine control of access to resources and ideas about racial groups in ways that typically disadvantage racially marginalized groups. Second, while still promising fair and equal treatment, racially disproportionate burdens can be laundered through facially neutral rules and via claims that burdens are necessary for unrelated reasons. Third, racialized burdens emerge when more explicit forms of racial bias in policies or administrative practices become illegal, politically untenable or culturally unacceptable. Racialized burdens neatly carry out the "how" in the production of racial inequality while concealing, or providing an alibi for, the "why."

Prepublication version of paper accepted in Journal of Public Administration Research and Theory

Key Words: Administrative Burdens; Racialized Organizations; Racialized Burdens

Acknowledgements:

We thank the anonymous JPART reviewers. Professor Moynihan's time on this project was supported by the Psychology of Administrative Burden (POAB) project, funded by the European Research Council, under the Horizon 2020 program (grant agreement no. 802244). 


\section{Introduction}

While much attention has been paid to how administrative burdens structure unequal access to public rights and services (Barnes 2021; Herd and Moynihan 2018; Heinrich 2018; Jenkins and Nguyen 2021; Masood and Nisar 2021), we theorize more explicitly about the role of race in this process. We argue that administrative burdens serve as the handmaiden of the racialized state: the experience of discrimination by state actors and processes often occurs via the experience of racialized burdens. Racialized burdens are a type of 'administrative practice' that normalizes and reinforces patterns of racial inequality in public services, simultaneously reproducing disparate treatment while obscuring discrimination because bureaucratic actors are "just following the rules." Racialized burdens emerge via intentional (but plausibly deniable) rules, or facially neutral rules that disproportionately harm marginalized racial groups. They can arise or be exacerbated in the context of policy design, as well as through the discretion afforded organizations and individuals in the context of implementation.

To establish this claim, we interrogate administrative burdens from the perspective of racialized organization theory (Ray 2019a), which presents organizations as racial structures that contribute to racial inequality, sometimes independent of bad actors or individual discretion. Racialized organization theory enables us to unpack how administrative practices become racialized, pushes us to consider how those practices arise in a public setting, and directs our attention to processes of both macro-level policy design and meso-level implementation via organizational mechanisms, as well as micro-level street bureaucratic discretion. The concept of racialized burdens serves both as a shorthand for conveying the symbiotic relationship between racialized organizations and administrative burdens, and as a variable for scholars to identify how racism, power and inequality present themselves in citizen-state relationships. It offers an 
alternate structural framework to understand what has been a "nervous" area for both public administration scholarship and practice (Gooden 2014).

Our approach complements streams of existing public administration research on race. One such stream focuses on how the racial composition of bureaucracies influence outcomes for both bureaucrats, such as teachers and police officers, and the people they serve (Meier 2019). Another stream of research focuses on street-level bureaucrat's use of discretion in ways that advantage whites and penalize non-whites (Alexander and Stivers 2010; Epp, Maynard-Moody and Haider-Markel 2014; Soss, Fording and Schram 2011; Watkins-Hayes 2011). Such work has been enriched by audit studies that empirically document how bureaucratic actors act upon racial biases (e.g., Olsen, Jeppesen and Moynihan 2020). These perspectives have generated invaluable insights by focusing on the micro-level with the individual bureaucrat as the unit of analysis, and street-level encounters as the venue of potential discrimination. While such work frequently acknowledges that the incentives, beliefs and motivation of individual bureaucrats are a function of macro policy design and meso-level organizational practice (Watkins-Hayes 2011), it does not make meso-level factors - in this case administrative practices - the unit of analysis.

By contrast, identifying racialized burdens refocuses attention to the meso-level of governance, linking macro-level government institutions and policies and individual, micro-level behavioral factors like discretion (Roberts 2020a). While administrative burdens are sometimes a function of legislation, such as voter ID requirements, or are more likely in some types of policy design, such as means tested versus universal policies, they are also patterned by mesolevel administrative practices in organizational settings that reinforce or buffer macro pressures. Administrative burdens also link to micro-level processes. For example, while shared racial identity between bureaucrats and clients encourage individual workers to use discretion in ways 
that resist or undermine rules to reduce burdens, policies and organizations ultimately set the boundaries for discretion (Barnes and Henly 2018; Watkins-Hayes 2011). Thus, racialized burdens co-opt bureaucrats who are personally supportive of racial equality but faithfully apply onerous administrative practices into the machinery of structural racism. In such ways, structural racism influences the behavior of even those who reject overt white supremacist ideology. Such administrative practices, to be durable, must be supported by macro-level policy design and cultural understandings, and meso-level implementation choices.

Both administrative burden and racialized organizations are relatively novel frameworks. We begin by synthesizing both approaches to develop the concept of racialized burdens. To show how racialized burdens operate, we examine their historical and contemporary application in contexts where individuals sought basic civil rights as immigrants, political rights through voting, and social rights through social welfare benefits. These illustrative examples demonstrate how macro-level processes set the stage for meso-level administrative practices in a way that fundamentally shape people's relationship with the state. We conclude by considering the utility of racialized burdens for the study of the state.

\section{Defining Racialized Administrative Burdens}

A central feature of administrative burden research has been to draw attention to the public's experience of the state. Doing so necessarily raises questions as to how administrative practices shape those experiences, and where those practices came from (Moynihan, Herd and Harvey 2014). The administrative burden framework and other public administration scholarship certainly acknowledges the role of race, discrimination and disparate outcomes (e.g. Alexander and Stivers 2010; Liang 2016; Meier 2019; Epp, Maynard-Moody and Haider-Markel 2014). And different accounts of the origins of burdens have pointed to ideological goals of policy 
actors (Baekgaard, Thomsen and Moynihan 2020, Bell et al. 2021; Herd and Moynihan2018), or other organizational rationales (Peeters 2020).

What racialized organization theory contributes to existing research is the capacity to unpack the mechanisms by which administrative practices are racialized. Racialized organizations theory adds a structural lens, which makes such an analysis more feasible, helping to document and explain why marginalized racial groups face more significant frictions when interacting with the state.

Emerging from sociology, and most clearly articulated by Ray (2019 a, b), racialized organizations theory assumes the state relies on organizations to govern (Brown 2020), and that those organizations are not race-neutral. Instead, the state is imbued with racial meanings (Bracey 2015; Jung and Kwon 2013; Omi and Winant 2014) that are contested, consolidated, and enacted through the collective organizational actions (Ray 2019a). Racialized organizations theory examines habituated patterns of codified cultural norms and resource distribution that exist beyond the preferences of the individual organization members. In doing so, racialized organizations treat administrative practices - including the application of policy requirements, organizational rules and resource distribution — as mechanisms for explaining persistent patterns of racial inequality.

Here, it is important to pause and consider what we mean by race in the context of racialized burdens. Race is a socially constructed relational category that organizations use as both rationale and justification for differential treatment (Ray 2019a; Tomaskovic-Devey and Avent-Holt 2019). Racialization is the relational process of ascribing racial meanings to objects, people, and processes. Importantly, racialization is not a synonym for non-white. All white or white dominated organizations are also racialized; white is also a race. Rather than simply a 
demographic characteristic or individual identity, race is a constitutive feature of organizational structures, as racial processes influence the likelihood of organizational founding, daily operations, and the chances of long-term organizational survival. Racialized organizations theory departs from this focus on individual racial identity or demographic composition because it argues that organizations themselves encode racial processes that shape individual racial identity. Organizations are racial structures that shape, channel, and sometimes limit how individual racial identity is expressed. Thus, the race neutrality central to some organizational theory is possible in the abstract, but in practice entrenched ideas about racial status mean that public and private organizations typically distribute resources in ways that advantage dominant racial groups. Racialized organizations theory is part of a broader movement of scholars increasingly focused on how race shapes organizational practices (e.g., Tomaskovic-Devey and Avent-Holt 2019; Wooten 2006). Seeing racialized relations as constitutive of organizations is key distinction with work that sees race as ported into organizations (Tomaskovic-Devey and Avent-Holt 2019) or work that sees minority racial identity or demographic composition (Wooten and Coulette 2017) as the key drivers of racialized organizations.

Racialized organizations theory consists of two main parts. The first part builds upon Sewell's (1992) discussion of social structures as "dual”- containing symbolic and material dimensions - and Acker's (1990) description of gender as inherent to organizational development and action. As racial structures, organizations combine ideas about race (schemas) with material and psychological resources. The second part of the theory is a set of four basic tenets that explain how these structures operate in practice (Ray 2019a): (1) racialized organizations enhance or diminish the agency of racial groups; (2) racialized organizations 
legitimate the unequal distribution of resources; (3) Whiteness is a credential; and (4) the decoupling of formal rules from organizational practice is often racialized.

Racialized organizational structures are simultaneously resilient and flexible. The resilience of organizational racial structures arises because they amass resources that allow them to last. The flexibility of racialized organizational structures comes from their ability to adapt. In novel historical conditions, organizations apply schemas of racial subordination to emergent resources, allowing new mechanisms of racial exclusion to develop. For instance, antidiscrimination law led to the emergence of new forms of exclusion when employers replaced "no Blacks" signs with covert, deniable hiring discrimination. Similarly, the opening up of student loan programs to Black students combined organizational resources in novel ways, creating a kind of the "predatory inclusion" (Seamster and Charron-Chenier 2015) where Black borrowers were offered loans on worse terms, partially eclipsing the benefits of higher education and contributing to the racial wealth gap.

Racialized organization theory helps to explain how administrative burdens are, and become, racialized. To date racialized organization theory has not been leveraged to understand how meso-level policy implementation, a core area of interest to public administration, affects racial inequality. Administrative burdens created or shaped by policy design often emerge as meso-level administrative practices that play out in implementation. These administrative practices are a mechanism that shape and channel agency by increasing the frictions that we experience when we interact with public services. Burdens include three subcategories. Learning costs like discovering program eligibility, or how to apply for and stay on public programs. Compliance costs include filling out forms, documenting one's identity and legal standing, 
waiting in line, or responding to bureaucratic directives. Psychological costs include stress, frustrations, anxiety, loss of autonomy, or a sense of stigma (Herd and Moynihan 2018).

We identify three key points from administrative burden theory that are relevant to the concept of racialized burdens. First, seemingly small burdens have large effects, substantially restricting access to basic rights, benefits and services. Second, these effects may be distributed unevenly, falling hardest on groups with less power or resources (Christensen et al. 2020; Heinrich 2016; Nisar 2018), including racial minority groups (Barnes and Henly 2018; Heinrich 2018). For example, for many young Black Americans, the most visible and salient face of the state is a coercive one that imposes costs, in the form of police (Soss and Weaver 2017) or child protective services (Edwards, Wakefield, Healy and Wideman 2021). Third, the construction of burdens, and their distributive effects arise as longstanding patterns of inequality are taken for granted and unthinkingly — or perhaps deliberately —incorporated into policy. To the extent that burdens are complex and opaque, their creation rarely debated, their outcomes difficult to discern, they serve to hide and normalize discriminatory goals (Herd and Moynihan 2018).

What basic theoretical claims become easier to discern and better grounded by synthesizing racialized organizations and administrative burden frameworks? First, racialized burdens combine access to resources and ideas about racial groups in ways that typically disadvantage racially marginalized groups. For example, many of the administrative burdens prevalent in welfare programs, such as elaborate documentation requirements to prevent fraud, are shaped by racist tropes like the ‘welfare queen’ (Kohler-Hausman 2007; Quadagno 1998). These racialized burdens then add labor, or the frustrations that come from dealing with bureaucracy, all disproportionately stealing time from racially marginalized groups (Barnes 2020). The daily interruptions and delays caused by racialized burdens make it harder for people 
of color to exercise personal agency and reflect the state's ability to impose differential restraints on people's use of time (Barnes 2020; Cohen 2018; Mills 2014). As described below, individual agency is undermined to the extent that burdens frustrate an ability to pursue basic citizenship rights.

Second, policymakers and organizations launder racially disproportionate burdens through facially neutral rules and via claims that burdens are necessary for reasons unrelated to race. This may be true even if racism is central to public or policymaker views about those justifications. For example, preventing fraud has been commonly employed as justification for burdensome welfare policies (Quadagno 1998). Administrative burdens often hide behind the legitimacy of the programs they are attached to, and the values those programs represent. Legitimating subtle barriers to program access helps policymakers and organizations appear neutral in principle while reinforcing racial inequality in practice.

Third, racialized burdens emerge as more explicit forms of racial bias in policies or organizational practices become illegal, politically untenable or culturally unacceptable. They evolve over time. For example, U.S. immigration policy in the early $20^{\text {th }}$ century shifted from specific nationality exclusions to literacy tests and public charge rules in ways intended to target the same groups (Ngai 1999). Racialized burdens neatly carry out the "how" in the production of racial inequality while concealing, or providing an alibi for, the "why."

These claims are explored in greater detail below.

\section{Racialized Burdens Are Inequality Producing Mechanisms}

Our work complements and draws from prior theories outlining the relationships between policy and race, allowing us to connect those theories to public administration practice in a novel way. First, building on Schneider and Ingram's (1997) discussion of the social construction of target 
populations by focusing on race, Soss and colleagues (2008) elaborate the racial classification model. They argue that race becomes important in the policy process when policymakers use racial categories and associated group stereotypes to create distinctions in policy outcomes. The racial classification model is a micro-level cognitive one, focused on the likelihood that policymakers will use racial cues. Racialized burdens are one way these micro-level cognitive foundations are institutionalized in meso-level organizations that mediate between citizens and the state. Second, the mechanism of racialized burdens meets the disproportionality and decentralization thresholds that Michener (2019) identifies as sufficient conditions for scholarly attention to race. Racialized burdens disproportionately target marginalized groups and are decentralized because implementation often devolves to state and local functionaries, as well as private agencies contracted out by the state to deliver services and benefits. In these ways, racialized burdens shape access to resources in ways that disadvantage minorities.

Critically, a focus on racialized burdens as inequality producing mechanisms allows researchers to show discriminatory harm, regardless of intent, (or even denial). Research into "racial institutional orders" argues that the American political system has always contained a racial element, even with a shift from an openly white supremacist order to a more formally egalitarian one (King and Smith 2005). Such racial hierarchies informed the design of policies and their implementation (e.g., Beckett and Francis 2020; Weaver 2007). Seminal figures in the development of the intellectual field of public administration were not exempt from such thinking, reflected in their views about American colonialism (Roberts 2020b) public employment (Aneja and Xu 2020), and immigration (Leonard 2017).

In the formally egalitarian environment, many policies and practices that create racial inequality are facially neutral. Theories of discrimination developed prior to the Civil Rights and 
Feminist movements explained ascriptive inequality based upon actors' motives. Following the Civil Rights movement, which delegitimated direct racial appeals (Bonilla- Silva 2010) in favor of coded racial language, hiding racist intent became a legal necessity, as open discrimination in public accommodations, voting rights, and schools was outlawed (and sometimes enforced). That is, the mechanisms producing racial inequality adjusted to a new historical context (Seamster and Ray 2018; Ray 2019a). The full distributive effect of burdens in such policies depends, in part, on macro institutional structures beyond policy design, ranging from the discriminatory practices in labor markets, which have affected racial wage disparities, to housing policies and real estate practices, which have shaped wealth racial wealth disparities.

Thus, macro-level factors that frame the nature of administration might both be racially motivated and facially neutral, directing and restricting the discretion of organizations and those that work inside them to use burdens as a tool. Scholars might try to observe the intent of policymakers, and the outcome, but with little knowledge of the organizational processes that connect the two. Thus, focusing on mechanisms, like administrative burden, allows scholars to move from the often unknowable "why" of discrimination to the more legible "how" (Reskin 2003). Attention to racialized burdens therefore allows the field of public administration to play a traditional and valuable role - exploring the black box of public services to connect administrative practices to broader policy design and effects. While administrative practices imply a wide array of potential action, the value of racialized burdens for policy actors is to enable the switch from openly racist appeals to the nominally neutral targeting of cumbersome, routine, bureaucratic minutiae disproportionately toward racially marginalized groups.

Even as some aspects of administrative burdens emerge from discretionary action on the part of the street-level bureaucrat, they are often incorporated into the legitimate rules of an 
organization or policy design, thereby compelling participation. To remain employed, following the rules requires workers put aside their personal aversions to differential treatment. For instance, Watkin-Hayes (2019) argues that levels of individual discretion are organizationally channeled such that intra-racial relations between clients and bureaucrats may be more constrained and class boundaries between provider and client might be greater for minority group members because they are subject to extra scrutiny by white bosses. Thus, the allegedly neutral bureaucratic rules themselves are decoupled and varying depending on the racial identity of the participant. To be clear, this reading is not an attempt to absolve individuals of complicity in harmful policies. But the point of institutionalizing administrative burdens is generally to direct and minimize individual discretion.

In this respect, racialized burdens become organizational tools, a set of administrative practices, that combine the agency shaping aspects of bureaucratic hierarchies and policy structures, with cultural ideas about groups to influence resource distribution. Buried in arcane rules, racialized burdens provide a colorblind gloss for policymakers that might be sanctioned for openly disenfranchising Black voters or denying welfare recipients their benefits. By complicating seemingly neutral policy preferences, politicians and administrators effectively leverage a tool to maintain white domination (Bracey 2015). Table 1 provides a general overview of how administrative burdens serve racialized organizations. 


\section{Table 1. Framing Administrative Burdens using Racialized Organizations}

Theory

1. Administrative burdens enhance or diminish or agency of racial groups by stealing resources like time.

2. Administrative burdens legitimate the unequal distribution of resources, in part via claims like fraud and deservingness, limiting access to basic rights and resources.

3. Whiteness is a credential that can be used and leveraged to reduce the experience and consequences of administrative burdens.

4. Administrative burdens allow for the use of discretion to decouple formal rules from organizational practice in racialized ways.

\section{Domains of Racialized Burdens}

Over time, the racialized origins and intent of administrative practices become normalized and hard to discern (Alexander and Stivers 2020). We therefore illustrate racialized burdens in three prominent domains of the US administrative state. In each case, burdens are central to historical patterns of deliberate exclusion. Our case selection reflects how racialized burdens relates to fundamental aspects of citizenship: becoming a citizen or some other formal legal status for immigrants; participating in the democratic political process as a voter; and accessing social benefits. We are inspired by T.H. Marshall's (1964) concept of citizenship rights, which argues that normative conceptualizations of citizenship should include what is needed to have standing and to live according to prevailing standards, which includes civil, social and political rights. Civil rights include basic legal rights and protections, which in turns depends upon having legal status as a citizen or another formal designation. We therefore start with the experience of racialized burdens in immigration. 


\section{Civil Rights: Racialized Burdens in Immigration}

From the start of the late 19th century to today, racialized burdens feature prominently in U.S. immigration processes. Whiteness has, literally, been a credential, both defining who can be a legal citizen in immigration law, how laws are enforced in practice, and shaping the experience and consequences of burdens. Presidents have used executive branch authority to imbue the immigration process with burdens that legitimate the exclusion of racially marginalized groups, in part by making the process so costly, in time and money, that many just give up. Table 2 provides an overview of how these burdens are racialized.

\section{Table 2. Racialized Burdens: Immigration Policy}

Tenets of Racialized Organizations Theory

1. Burdens diminish agency of racially marginalized groups

2. Burdens legitimate unequal distribution of resources

3. Whiteness is a credential that eases burdens

4. Decoupling of formal rules from organizational practice in ways that racialize burdens
Examples of Administrative Burdens as Racialized Weapons

Uncertainty about access to legal immigrant status, imposition of greater compliance costs directed towards racially marginalized groups. Legitimate unequal access to citizenship, in part by reinforcing deservingness, fraud and disease tropes toward racially-marginalized groups. Immigrant access to citizenship historically conditional on whiteness. More onerous contemporary burdens, such as those arising from public charge, metering or Remain in Mexico policies, largely exclude whites. Informal discretion allows administrators to target burdens toward racially marginalized groups.

From 2016-2020 the Trump administration dramatically changed the nature of US immigration policy and practice, reducing the ability, and thereby agency, of both legal and 
undocumented immigrants to enter the country. It did so without a single piece of legislation, operating entirely through executive branch power. While some changes effectively altered the eligibility of who could enter, others made the process of getting to and staying in America harder via burdens that disproportionately affected racially marginalized immigrants (Moynihan, Herd and Gerinza, in press).

While the Trump administration's actions were labeled at odds with an American ethos of welcoming immigrants, many of the tools employed echoed previous eras of anti-immigrant sentiment. For example, the Trump administration expanded the naturalization test for citizens, adding more questions. The origins of the citizenship exam are found in the 1906 and 1952 Immigration Acts, which added English language and civic requirements during periods of antiimmigration xenophobia. The Trump administration also resurrected the public charge principle, which limits immigration opportunities for those who might become dependent upon state benefits. The result was to increase compliance costs by forcing individuals to document financial resources, with the burdens falling disproportionately on those from majority non-white populations (Moynihan, Gerinza and Herd, in press). Using the public charge principle to reduce the agency of racially marginalized groups is not new. It has been used, with varying degrees of intensity, since the 1880s. Its aggressive application during the Great Depression meant that refugees struggled to enter the United States, including Jewish refugees seeking to exit Austria and Germany before World War II. The public charge principle also reflects how immigration restrictions and administrative burdens have been legitimated by claims of fraud, abuse, and the dangers posed by racially marginalized groups. Despite evidence that immigrants pay more into the tax system than they receive in social services, and are less likely to be involved in crime than native born citizens, anti-immigrant forces legitimate administrative burdens through false 
claims that migrants are a drain on collective resources or criminals (Moynihan, Herd and Gerinza, in press).

In other areas, US immigration policy moved from explicit racial designations to colorblind policies that nonetheless targetes racially marginalized groups with burdens, effectively maintaining whiteness as a credential. Citizenship was formally reserved for whites from 1790 until 1952, although what "white" meant in this context evolved with broader social acceptance of immigrant groups (Haney Lopez 1997). In the early 20th century, for example, while Mexicans were considered 'white' under the law, by the late 1920s, the US looked to administrative means to keep them out. Using the public charge rule, literacy tests, and bans on contract labor, the number of Mexican laborers fell from approximately 58,000 a year in the late 1920s to 3,333 in 1931 (Ngai 1999; 90).

Contemporary language surrounding "illegal immigrants" — characterized as cheaters who need to "get in line" and naturalize the right way — is used to legitimate how the immigration process, via burdens, shape the agency of racially marginalized groups. This language justifies exceptional burdens around the naturalization process, which takes years and requires navigating a byzantine bureaucratic process. When the Trump administration restricted travel from Muslim majority countries, or limited student visas from African or Middle Eastern countries, the formal justifications evoked out-group threat, made on national security rather than racial grounds, but the effect was to exclude non-white groups. Additional restrictions on border crossings were justified on public health grounds as the COVID-19 pandemic emerged, again with the same effect of restricting immigrants from racially marginalized groups (Moynihan, Herd and Gerinza, in press). 
The Trump administration also differentially restricted peoples' agency by stealing time. For example, it reduced staffing and closed overseas consuls, as well as offices that provided help to refugee applications, even as they demand more documentation from applicants, and required in-person interviews for some applicants seeking to enter the US in a form of "extreme vetting." Such changes increased learning costs for those asked to understand the new policies, compliance costs via delays and additional documentation, and psychological costs via stress and frustration.

Applicants for refugee status presenting themselves at the border faced similar burdens, in more dire circumstances. While international law confers a right for a case hearing, the Trump administration adopted administrative processes to effectively void such legal rights. This included "metering", deliberately slowing the process of applications, creating months-long backlogs. The Migrant Protection Program required asylum-seekers to stay outside the US while they waited for a hearing, typically in Mexican border towns, often in highly dangerous conditions. New interview standards compelled asylum seekers to provide material documentation of the risks they faced that in many cases were simply impractical to attain (Moynihan, Herd and Gerinza, in press; O’ Toole 2019).

Learning costs increased as policies rapidly changed, even as the policy on the ground failed to reflect the formal policy, or international law, leaving applicants vulnerable to rumors and uncertainty. Compliance costs increased—more documentation required, longer wait times in sometimes precarious conditions that drained migrant resources and separated them from family members. Consular officers were encouraged to limit the length of visas, requiring more frequent renewals. Undocumented immigrants living in the US not only faced greater scrutiny and risk of deportation, they also had fewer rights if they entered deportation programs, 
including an ability to request delay to seek legal counsel. State governments could augment federally-induced burdens with their own, by, for example, changing documentation requirements to effectively exclude undocumented immigrants from public services (Heinrich 2018). Psychological costs have increased in parallel: as the process becomes more complex, longer and unforgiving, so to do the stresses and frustration. As migrants are exposed to more dangerous conditions, including being subject to kidnapping in border towns where they are forced to wait, or separated from family members if admitted to the United States, they are exposed to severe distress (O’ Toole, 2019).

As grim as these policies are, we again find parallels in US history. In the run-up to and during World War II, nativist members of the State Department used similar tactics to block the migration of Jewish refugees (Herd and Moynihan 2018). The purpose of these burdens has been to make the U.S. immigration process so costly, in time and resources, that potential migrants, disproportionally from marginalized racial groups, lose agency and give up.

\section{Political Rights: Racialized Burdens in Voting}

In this section, we detail the use of racialized burdens to disempower and limit perhaps the most important form of political agency in the context of a democracy, the right to vote. We detail particular strategies used to legitimate this practice, ranging from seemingly colorblind laws to accusations of fraud. We also demonstrate the ways whiteness acts as a credential, both protecting, and even enhancing, access to the vote. 


\section{Table 3. Racialized Burdens: Voting}

\begin{tabular}{ll}
\hline Tenets of Racialized Organizations Theory & Examples of Administrative Burdens as Racialized \\
& Weapons
\end{tabular}

1. Burdens diminish agency of racially marginalized groups

2. Burdens legitimate unequal distribution of resources

3. Whiteness is a credential that eases burdens

4. Decoupling of formal rules from organizational practice in ways that racialize burdens

Ability to achieve political vision frustrated by disenfranchisement. Disproportionate impact of burdens such as longer wait times consequently steal more of Black voters' time.

Claims of fraud legitimates the disenfranchisement of Black voters.

Historically, white people less subject to burdens such poll taxes or literacy tests. Policies such as voter ID reduce wait times for white voters while increasing it for Black voters Administrative discretion results in more help for white voters, and more challenges to Black and Latino voters.

Following the $13^{\text {th }}, 14^{\text {th }}$ and $15^{\text {th }}$ constitutional amendments, the architects of Jim Crow were forced to create an illusion of legal race-neutrality even as they designed race-targeted burdens (Whitman 2017). Ostensibly race-neutral literacy tests and poll taxes disproportionately imposed compliance costs on Black Americans, eroding their democratic agency (Anderson 2018). Recent work has unearthed the centrality of burdens to disenfranchisement efforts, and their long-term consequences (Keele, Cubbison and White 2021). The 1898 Louisiana constitution was typical in its use of burdens via literacy tests, poll taxes and property requirements. A grandfather clause that exempted anyone who had voting rights prior to Reconstruction, and their sons and grandsons, only benefited whites. The net effect was long- 
lasting. Black voter participation in Louisiana was above whites prior to the constitution, was effectively eliminated with its adoption, and did not return to parity until more than 100 years later.

The past decade has seen a resurgence of burdens in voting. Such burdens reflect a growing partisan belief that limiting the ballot helps the Republican Party, and a judicial willingness to allow restrictions. Most notably, in 2013 the Supreme Court overturned parts of the Voting Rights Act that blocked election practices that would disproportionately hurt voters of color. Since the 2010 wave election that empowered Republicans, 15 states passed voter ID laws, 12 states have made it harder to register, including mandated requirements to purge voters from the rolls, and 10 made it more difficult to vote early or absentee (Brennan Center for Justice 2019).

Both historically and today, whiteness serves as a credential easing access to the ballot. In the Jim Crow era whiteness largely exempted voters from the burdens that legitimated disenfranchisement of Black Americans. The alleged impartiality of poll taxes was belied by their prohibitive expense for impoverished Black sharecroppers, or by the requirement forcing Black voters to go before notoriously brutal southern sheriffs to register, with dangerous consequences if they actually did so (Anderson 2018). In some cases, Black voters had to bring white witnesses to the register (Herd and Moynihan 2018). White and Black voters both took literacy tests, with Black voters' tests held to higher levels of scrutiny or tossed out.

Discretion and the decoupling of formal rules and organizational practices plays a critical role in how burdens are racialized. In the Jim Crow era, state legislatures gradually invested more discretion in election officials as tools like poll taxes were declared illegal, under the assumption that street-level bureaucrats would use their discretion in ways aligned with 
legislative desire to help illiterate white citizens and block Black citizens. For example, a politician in Alabama called for literacy tests to include subjective elements, such as the ability to interpret the constitution, to "give certain discretion to the Board of Registrars and prevent them from registering those elements in our community which have not yet fitted themselves for self-government" (Herd and Moynihan 2018, 46). While such overt discrimination is unlikely today, clerks enjoy significant power that allows them to shape voter participation consistent with their preferences. For example, one audit study found that local election officials were less likely to provide a response or quality information to Latino names relative to white ones (White, Nathan and Faller 2015). Minority groups are consistently more likely to be asked for IDs, and the differences are more pronounced in states where poll workers have greater discretion (Atkeson et al 2010).

State issued voter IDs to register or vote, which are required by macro-level laws, provide a robust illustration of how their racialized effects are exacerbated in implementation. For example, one study found that voter IDs increased wait times in polling places used by Black voters, but reduced wait times for voters in white-dominated polling places (Stein et al. 2020). Longer lines and wait-times decrease turnout, and these burdens disproportionately fall on Black voters (Barreto et al 2009). Smartphone data shows residents of predominantly Black neighborhoods spend more time waiting at polling places (Chen et al. 2020), and Black and Latino voters reported waiting $45 \%$ and $46 \%$ more time, respectively, than white voters in 2018 for example (Klain et al. 2020).

Burdens are legitimated via fraud claims. Such claims have consequences. Historically, Black voters registering to vote faced threats from white supremacist groups. Today, voters still worry about being accosted by poll watchers. In 1981, the Republican Party was barred by a 
consent decree from organizing poll watchers after they posted armed and uniformed private contractors to polling places in predominantly Black and Hispanic neighborhoods on the premise of fighting fraud. The consent decree was lifted in 2018, even as President Trump used voter fraud concerns to recruit an "election security operation." Trump's baseless claims, most frequently directed at jurisdictions with large proportions of Black voters, has undermined faith in basic democratic processes among large numbers of his supporters, and serves as a justification for laws that further restrict voting access.

In some cases, the line between historic strategies to legitimate disenfranchisement and current practice is unbroken. Eleven states prevent current and former felons from voting. More than 5 million potential voters are disenfranchised as a result, compared to just over 1 million in 1976 (Uggen, Larson, Shannon and Pulido-Nava 2020). Florida's felon disenfranchisement law was the most egregious, blocking about one quarter of all disenfranchised felons in America (Mower and Taylor 2020), and tracing its roots back to post-Reconstruction policies targeted at newly enfranchised Blacks. Given how racism has shaped the criminal justice system, such laws both disproportionately target Black Americans and meaningfully affect the composition of the electorate (Phillips and Deckard, 2015). Over 6.2\% of the Black adult population have lost voting rights through such felon disenfranchisement laws, compared to $1.7 \%$ of others (Uggen et al. 2020).

The disenfranchising of Black voters via felon laws even had spillover effects on nonfelons, racializing a new set of burdens. Such burdens likely determined the outcome of at least one presidential contest. In 2000, the Florida felon disenfranchisement law was used to justify an aggressive purge of the voting rolls of former felons. The purge also removed an estimated 
12,000 non-felons, disproportionately Black voters, undermining their participation in an election that gave George W. Bush the Presidency by a margin of 537 votes (Berman 2015).

Popular efforts to restore the franchise to former felons were blocked by new administrative burdens. In 2018 Floridians overwhelmingly voted to eliminate the felon voting ban. Immediately after, Republican legislators required an estimated 800,000 felons to pay off court fines and fees before they could vote. The fees are a compliance cost that in some cases were unaffordable for the former felons. The link between payment and voting evokes the poll taxes of the past. Former felons also faced considerable learning costs. The fines-and-fees system involve multiple jurisdictions, plus for-profit private debt collectors. Strikingly, according to the 11th Circuit Court of Appeals, the state has no obligation to tell people how much they owe or whether they've met these requirements. Potential voters also face the psychological cost of stress and uncertainty. If they vote based on a mistaken belief they have satisfied the state requirements, they could return to prison on felony charges. Such burdens were successful at maintaining the status quo. Two years after the referendum striking down the law, just $8 \%$ of eligible former felons had registered to vote for the 2020 election (Mower and Taylor 2020).

\section{Social Rights: Racialized Burdens in The Safety Net}

The social welfare system in the United States has been embedded with racialized burdens throughout its history. Both the design and actual distribution of these benefits, which comprise $40 \%$ of the federal budget, inhibit the agency of Black Americans in particular, stealing their time, while simultaneously legitimatizing the racialized distribution of benefits by limiting access via justifications centered on fraud and deservingness (see table 4). A national survey found that Black and Latinos applicants were 3 times as likely to say they experienced 
discrimination when applying for welfare services or public assistance because of their race, with the highest rates of perceived discrimination for those with the lowest incomes (Pratt and Hahn 2021). These burdens are enhanced with high levels of bureaucratic discretion, or their decoupling of formal rules from organizational practice, which allows for their racialized administration. In this segregated and decoupled system of benefits, whiteness again operates as a credential, more often shielding white Americans from the consequences of these burdens.

\section{Table 4. Racialized Burdens: Social Policy}

Tenets of Racialized Organizations Theory

1. Burdens diminish agency of racially marginalized groups

2. Burdens legitimate unequal distribution of resources

3. Whiteness is a credential that eases burdens

4. Decoupling of formal rules from organizational practice in ways that racialize burdens
Examples of Administrative Burdens as Racialized Weapons

Racially marginalized groups more dependent on means-tested programs that consume more time and effort to establish eligibility and maintain benefits.

"Deservingness" and fraud tropes legitimate making it more difficult for marginalized racial groups to access social benefits.

Whiteness secures access to less burdensome benefits, even without work credentials, e.g., white women with Social Security survivors benefit. Whiteness also confers social resources that advantages white people within bureaucracies.

Bureaucratic discretion employed in ways that systematically advantage white beneficiaries and disadvantage Black beneficiaries in terms of access to social welfare benefits, e.g., Black veterans less able to claim GI Bill benefits.

Racialized burdens were present at the origin of the first major US welfare system: pensions for Civil War veterans (Skocpol 1995). Here, colorblind laws failed to account for Black veterans differing historical relation to citizenship, with the result of both undermining 
their agency and legitimizing unequal benefit distribution. Slavery as an institution created a path dependency that reduced Black peoples' agency in bureaucratic procedures that followed abolition. Black veterans were less likely to be literate, or have the financial resources necessary to navigate bureaucratic hurdles. Because many dropped their enslaver's name following emancipation, newly freed people often lacked the paperwork necessary to satisfy documentation requirements (Shaffer 2000; 136). As a result, a much smaller fraction of Black veterans accessed these pensions relative to their white peers.

Black veterans of World War II faced similar challenges. Racialized burdens also reduced their agency, while legitimating a decentralized process of benefit distribution stacked against them. The GI Bill was a federal program, ostensibly colorblind in the promise of benefits. Southern senators whose votes were necessary for the passage of the bill feared that such benefits would undermine the Jim Crow racial order. And so, the program was designed to filter federal resources through local Veterans Administration offices. Here, local public officials and private actors, such as loan officers and banks, devised burdens to exclude Black veterans (Katznelson 2005). The result was to constrain Black Americans access to a wealth generating mechanism that proved central to the mid-twentieth century growth of the white middle class (Oliver and Shapiro 2006).

Social welfare programs that evolved out of the early 20th century and into Roosevelt's New Deal contained the racialized roots of the administrative burdens we see in many meanstested social programs today. The degree to which beneficiaries must 'prove' their eligibility, via complex forms and intensive documentation requirements, reflected the views of early designers and administrators, primarily white upper- and middle-class social workers (Gordon 1991). Programs were designed to support women's primary role as homemaker (Mink 1998). But the 
maternalist philosophy did not extend to poor, and predominantly Black and immigrant women. Their poverty was judged a result of 'individual character defects' rather than structural conditions. Resources for the poor were therefore conditioned on burdensome and invasive bureaucratic requirements, such as frequent unexpected home inspections from social workers and the general sense that the women needed close monitoring (Mink 1998; Gordon 1991; Mettler 1998). Contemporary debates still reflect such considerations. Proposals to expand the Child Tax Credit, for example, must consider if it should be tied to work, a consideration not present in peer countries that make a children's allowance a direct benefit to parents. The conditionality of child benefits hurts families with the lowest earnings, excluding about one third of white children, $45 \%$ of Hispanic children and nearly half of Black children from the full credit (Institute on Taxation and Economic Policy 2021).

Contemporary racialized burdens in social welfare programs are rooted in their historical design. Racially marginalized groups are more likely to be served in means-tested social welfare programs that impose higher levels of administrative burdens on beneficiaries, including Temporary Aid to Needy Families (TANF), the Supplemental Nutrition Assistance Program (SNAP), and Medicaid. By contrast, white beneficiaries are disproportionately served in social insurance like Social Security and tax subsidy welfare programs like employer-based health insurance where administrative burdens are borne by government or private bureaucracies instead of beneficiaries (Herd et al. 2016).

The shifting of administrative burdens from the state, or organizations, to beneficiaries for means-tested program has significant consequences in terms of stealing time from racially marginalized groups and their access to benefits. Means-tested benefits like SNAP or Medicaid require lengthy eligibility forms, substantial documentation of employment and earnings, 
interviews, and recertification as frequently as every 6-12 months. By comparison, one need only fill out a short form to receive Social Security; the government and employers keep track of marital status and lifetime earnings to define eligibility and benefit size. The differences in the racial composition of these two categories of social welfare programs, and thus the racial distribution of administrative burden, are large. Black people are twice as likely to rely on Medicaid coverage and two-thirds as likely to have employer-based health insurance (Kaiser Family Foundation 2020). Black women, as compared to their fraction of the population, are more likely to draw on means-tested benefits, such as SNAP and TANF, whereas white women benefit more from spousal and survivor Social Security benefits (Herd 2005; Harrington Meyer 1996). While some ascribe the low levels of burden in Social Security as a function of it being an earned entitlement, it's important to note that eligibility for spousal and survivor benefits simply requires having a 10 -year marriage. Nearly $60 \%$ of women receive Social Security based on their marital status, either as a wife or a widow, but white women disproportionately receive these benefits. Indeed, for the 1960 birth cohort, $80 \%$ of white women are eligible compared to just $50 \%$ of Black women (Harrington Meyer 1996). Thus, a primary welfare benefit offered disproportionately to white women is not 'earned' by the recipient.

These differences extend also to forms of welfare administered by private actors. Individuals receiving subsidies for their employer-based health insurance, which disproportionately benefit whites, are similarly unburdened. In fact, the process is so seamless that most Americans don't even realize such subsidies exist, to the tune of $\$ 250$ billion per year, or consider themselves welfare recipients by virtue of receiving such public largesse (Mettler 2011). The end result is that while everyone eligible receives Social Security and subsidies for 
employer provided health insurance, only between 50-80\% of those eligible receive means-tested benefits like SNAP and Medicaid (Herd and Moynihan 2018).

This is not to say that white beneficiaries are immune from administrative burdens in welfare programs. The collateral damage that these policies inflict on low-income whites legitimates claims of race neutrality and the denial of racialized intent. Such an approach feeds a “divide and conquer" political strategy, helping to undermine policies portrayed as benefitting, for example, Black people (Quadagno 1994). Such legitimations also explain the paradox that while more white people receive welfare, the visual images that people see and associate with welfare are negatively-framed images of people of color (Gilens 2009). Indeed, there is robust evidence that the attacks on federal welfare programs, some of which had been around since the 1930s, parallel with Black beneficiaries gaining access to these programs (Quadagno 1994). Further, there is a wealth of evidence that targeted programs in states that have higher fractions of Black beneficiaries have higher levels of burden. For example, the numbers of Black beneficiaries on state caseloads correlates with more punitive welfare rules, such as harsher sanctioning, specifically losing benefits when beneficiaries make procedural mistakes (Hahn et al. 2017; Soss et al. 2001).

Burdens are legitimated through claims that it's about deservingness, not race. Many Americans view poverty as a moral or individual failing, justifying large burdens within meanstested social welfare programs. But the fact that Black people are systematically more likely to draw on means-tested poverty-based benefits reflects longstanding institutional racism embedded everywhere from schools to housing and the workplace. The threat of fraud offers an additional justification for imposing disproportionate burden that recipients of means-tested programs face. Welfare fraud itself is understood by the mass public in explicitly racialized terms (Gilens 2009). 
It's no accident that President' Reagan's archetypal 'welfare queen' was understood to be Black (Kohler-Hausman 2007), though she was of mixed race and often assumed a white identity.

Bureaucratic discretion can further entrench racial inequalities, in part by enhancing whiteness as a credential. Discretion is applied unevenly to Black and white claimants in traditional welfare programs like TANF. Welfare case workers, for example, are more likely to penalize Black participants for failing to navigate burdens, such as missing an appointment, while white beneficiaries are given the benefit of the doubt (Schram et al. 2009). Whiteness as a credential has a layered impact in this context. It influences both the composition of case workers in organizations, in terms of who is hired and promoted, but it also influences how these case workers perceive and treat welfare claimants. Whiteness, or its markers, serves as a social resource that helps people navigate burden. Tressie McMillan Cottom (2019:162) details how her mom helped a neighbor who'd been denied benefits in a "genteel bureaucratic way—lots of waiting, forms, and deadlines that she could not quite navigate." Cottom describes how there was

“something about my mother's performance of respectable black person — her Queen's English, her Mahogany outfit, her straight bob, and earrings" that "got done what the elderly lady next door had not been able to get done in over a year." But as she notes, it's not costless "to signal to gatekeepers that we were worthy of engaging" and it doesn't always work.

\section{An Agenda to Study Racialized Burdens}

Racialized burdens are mechanisms of state power that undermine the citizenship rights of racially marginalized groups, reinforcing patterns of inequality. Applying a racialized organization perspective allows us to answer core questions posed the administrative burden framework including "How are burdens used as policy instruments?" "What are the effects of 
burdens on citizens?", and "How do administrative burdens affect inequality?" (Moynihan, Herd and Harvey 2014).

A reasonable concern is whether it is possible to draw a sharp distinction between racialized burdens and other types of burdens. After all, burdens will inevitably affect some marginalized groups. We acknowledge the potential for ambiguity, but this is precisely why systematic research on this topic is so badly needed. Claims of institutionalized racism need both evidence of their existence and how they work, and the concept of racialized burdens helps with both. The alternative - an inattention to the topic that defaults to an assumption of administrative neutrality - is neither sustainable nor empirically justified. Our examples support the premise that racialized burdens do not incidentally fall on racially marginalized groups: they are historically designed to do so while maintaining a myth of formal race neutrality. In doing so, racialized burdens link the overt racism of the pre-Civil Rights era with contemporary colorblind denialism (Bonilla- Silva 2010), providing public organizations with both racialized procedures and plausible deniability (Ray and Purifoy 2019).

Public administration scholarship is well positioned to identify racialized burdens, examine the administrative machinery and intent behind them, and understand their effects. By contextualizing administrative burdens in racialized organizations, we make administrative practices the unit of analysis, rather than micro-level individuals or macro-level policy design. This, for example, allows for an examination of structural racism in a way that focusing only on individual bureaucratic discrimination cannot. It also helps us unpack how aspects of policy design become racialized burdens in the context of administrative practices. Below, we offer some preliminary suggestions for how this might be done, as well as draw some lessons from our 
examples. These lessons suggest that by focusing on the history, justifications, intentionality and tools tied to administrative practices, researchers will unearth racialized burdens.

\section{The Past as Prologue: Unearthing the Roots of Burden}

Understanding relationships between public organizations and race requires a deeper historical understanding of the roots of burdens, and the racialized soil from which those roots emerge. The progeny of burdens employed in, for example, Civil War Pension system, social welfare programs, voting procedures, and immigration in the late 19th and early 20th are found in contemporary administrative practices. The historical reoccurrence of administrative patterns and justifications that disempower racially marginalized groups is a compelling argument for their durability and intentionality.

Attention to history reveals not just the persistence and mutations of racialized burdens, but provides a deeper understanding of why they emerge and evolve. Across our examples, racialized burdens are most easily observed when forms of overt racism are no longer viabledeemed illegal, or politically or culturally unacceptable_-but racial intent remains. In immigration, xenophobic statements of political sponsors occur alongside the imposition of burdens that claim racial neutrality. In voting, Jim Crow era burdens emerge after constitutional amendments, and evolve as tools such as literacy tests are gradually deemed illegal. The relaxing of legal constraints, most notably the Supreme Court decision to remove the preclearance provisions of the Voting Rights Act, gave life to a new wave of burdens. The close connection between racially coded dog whistles in welfare with racially impactful burdens reiterate how burdens bridge illegal racial discrimination and legal racially disparate outcomes. 
Studying racialized burdens therefore requires both retracing the history and origins of particular rules, practices, procedures, policies, or memos that give rise to burdens, while connecting those administrative actions to the historical context in which they emerged. This is a blind spot for the field of public administration, which is more attentive to its intellectual history and the great books of an earlier age than to the historical context of administrative practice, and especially to the role of race in that context (Alexander and Stivers 2020; Roberts 2020b). This historical amnesia prevents us from seeing how actual projects of administrative design constructed racialized burdens that are left largely unmentioned in administrative theory. For example, while Woodrow Wilson's writing on public administration remains canonical, it needs to be considered in the context of his administrative practice of resegregating federal offices as President (Aneja and Xu 2020).

\section{Common Justifications}

The political sphere demands some justification for administrative action. How then, does power justify burdens? Examining those justifications offers an opportunity to study how racialized burdens are rationalized.

Close attention to justifications is important, given that public actors might be reluctant to be frank about racial intent. Explicit invocations of race were more common in the past, but we still find contemporary examples (Moynihan, Herd and Gerinza, in press). A second and more frequent type of justification, more apt to appear in the administrative domain, instead uses the language of seemingly neutral administrative values such as efficiency, innovation, or claims about fraud or illegality, or lack of deservingness in some way. The latter type of rationalization reflects a third type of justification from the political domain, one which is not explicitly racial 
but relies on coded language that plays upon macro-level stereotypes (Omi and Winant 2014). Public campaigns against welfare (Quadagno 1994), voting rights (Anderson 2018), and immigration (Brown 2013) all rely upon racialized tropes of deservingness to justify administrative burdens. Racially marginalized groups are presented as threats: people intent on taking something - a welfare benefit, citizenship, a house in a historically white neighborhood, the right to vote - they have not earned, deserve or are capable of managing.

Such framings are important in obscuring racialized intentionality, and normalizing practices in ways that make them acceptable to employees and the public. The most effective type of justification is the one that never needs to be made, the claim that goes unquestioned. Racialized organization theory alerts us to the persistence and power of normalization of assumptions by organizational actors. The job of the researcher therefore is twofold. First, to unearth and identify such assumptions and their formation and persistence within the organization. Second, to examine how justification for racialized burdens depend upon racialized beliefs.

Attention to justifications for racialized burdens raises two further questions. First, how do such justifications not only rationalize burdens, but also serve a source of burdens, specifically psychological costs? Messages that marginalize groups go not just to the mass public, but also to the subjects of those messages, who internalize or must invest effort in resisting administrative communications that they are untrustworthy or incapable. Second, to what degree does the administrative machinery, including the people who work in it, internalize and communicate these rationalizations?

\section{Common Tools and Strategies}


While our case studies are illustrative by nature, they point to unmistakable commonalities across time and policy areas in the deployment of racialized burdens. These commonalities can be divided into tools and strategies, both of which are merit more attention.

Many of the tools we describe are familiar to students of administrative burdenscomplex and contradictory procedures, demands for form-filling and documentation, rituals of administrative degradation and humiliation. A demand for documentation such as birth certificates is a staple of welfare policy, voting, and immigration. It would be illuminating to track these tools across time and policy domains. Providing the sort of historical context described above makes their use as racialized burdens clearer. For example, literacy tests, including demands for civic knowledge, used to disenfranchise Black Americans in the Jim Crow south were also deployed via the Immigration Acts of 1906 and 1917 to provide immigration officers with a tool to prevent southern and eastern Europeans from entering the country. Similarly, the public charge rule that began in the colonial era (Law 2014) was used as a tool to discourage the emancipation of slaves by requiring a bond to ensure they would not become dependent on the state.

In addition to specific administrative tools, it is important to understand strategies that shift power and resources in ways that increase racialized burdens. One such strategy is reducing organizational resources. Such reductions are rarely explicitly justified as a means to facilitate burdens. Instead, they are framed as part of austerity politics or a need for efficiency. But the result is a diminished state where burdens are shifted onto target populations, resulting in longer lines to vote in urban areas, or a dysfunctional welfare application process. For example, the Trump administration moved officials away from border entry processing positions, shuttered offices dedicated to helping refugees and attempted to furlough employees who deal with 
applications as part of a broader strategy to increase burdens in immigration (Moynihan, Herd and Gerinza, in press). How, and through what mechanisms, do organizations make choices about how to deploy constrained resources in ways that lead to disproportionate impact? How do organizational employees perceive and understand such actions?

Power may be shifted—reducing or increasing bureaucratic discretion, to other levels of government or to private providers of public services - in ways that make racialized burdens more likely. For scholars of street-level bureaucracy, devolution, collaborative governance or privatization this poses a common question: where do governments locate public power, what conditions do they place upon its use, and what are the consequences for racialized burdens?

For bureaucratic discretion, our examples show situations where street-level bureaucrats sometimes found their discretion enhanced - in the case of election clerks during the Jim Crow era-or reduced — in the case of some immigration officials in the Trump era. Discretion does not have an axiomatic relationship with burdens. Rather, the focus on how discretion is structured and used is, from a racialized organizations perspective, not an end in itself but compelling to the degree it facilitates disparate outcomes. The observation is complicated by the fact that many organizational directives both increase and reduce discretion at the same time (Moynihan and Soss 2014). For example, a citizenship verification requirement for a benefit like Medicaid gives administrators new individual-level discretion that could lead to increased discrimination within the target population of potential non-citizens, but ultimately such officials are now forced to account for non-citizens among those seeking benefits. Even as they might use their discretion to help at the margins, they are in aggregate serving to enforce racialized burdens. 
Such discussions of discretion demand an employee perspective (Watkin-Hayes 2011). How do public employees recognize and respond to the patterns that we describe? Are there cases where they actively welcome such patterns and come to identify with them? Crises of legitimacy in policing and immigration services are, for example, partly crises of a perceived rejection by street-level bureaucrats of explicit critiques of the racialized nature of their organization. The use of discretion returns us to a micro-level perspective on administrative action, but an awareness of racialized burdens pushes us to better understand the meso context.

Another power-shifting strategy is decentralization. The shifting of policy from federal to state and local governments allows for meso-level administrative practices to racialize burdens. This is more likely in settings where there is macro support for such administrative actions (Michener 2018, 2019; Mettler 1998; Soss, Fording and Schram 2011). Such a pattern preceded the creation of federal administrative capacities. Until the late $19^{\text {th }}$ century, individual states, not the federal government, constructed migrant policies in ways that not just constrained the movement and entry of immigrants, but also of Black people: "The northeastern states were trying to protect themselves against an influx of the poor, sick, and convicted, who could become local economic and social liabilities. The southern states wished to preserve and upkeep their slavery system, so ceding control to the national government over policies that impinged on the movement of persons was unthinkable" (Law 2014, 109). To offer more recent examples, the 1996 federal welfare reform that radically devolved power to states enabled the creation of racially disproportionate burdens (Soss, Fording and Schram 2011). Similarly, the 2013 Shelby vs. Holder decision to remove federal oversight of election administration ushered in a new wave of burdens on voting in regions that had historically used such burdens to disenfranchise Black voters. 
Shifts of powers may result in racialized burdens even in cases where the rationale for the shift is democratic devolution, innovation, or efficiency, but the result is to locate power in less transparent settings and accompanied by incentive structures friendly to the creation of burdens. For example, private organizations are less subject to public scrutiny, less constrained by procedural demands for due process, and more responsive to incentive structures. Private providers of public services have an incentive to use burdens to engage in statistical discrimination-excluding groups they consider less profitable (Jilke, Van Dooren and Rys 2018; Soss, Fording and Schram 2011). Thus, the logic of racialized burdens is outsourced from the public actor, and internalized and accepted by the private actor without any explicit discussion of race, enabled by the overlapping logics of public and private co-production.

\section{CONCLUSION}

In this article we introduce the concept of racialized burdens as an alternate framework to investigate and understand the role race in administrative practices. We argue that administrative burdens serve as a racialized weapon used by policymakers and state organizations. Our examples illustrate how these burdens differentially distribute status, resources and punishment. Whiteness signals deservingness, funneling white people towards access to citizenship, easier mechanisms to vote and less burdensome social welfare policies. Ultimately, these burdens shape the agency of racially marginalized groups by limiting their legal rights and access to resources.

What does the addition of a racialized organizations perspective add to traditional frameworks of public administration, including administrative burdens? Logics of discrimination drawn from economics, such as statistical and taste-based discrimination, emphasizes microlevel processes. Theory from political science, while valuable, often overlook meso-level 
processes, particularly administrative mechanisms that are a core interest to public administration. By contrast, applying the meso-level focus of racialized organization theory focuses on administrative practices. Applying this perspective to the administrative burden framework puts greater weight on pre-existing claims, such as the need to understand heterogenous responses to and effects of administrative burden. While much of our account has provided a logic of how racialized burdens emerge and generate disparate outcomes, there is also much we do not know about the internal workings of racialized public organizations. It is not only that we need to better understand if burdens generate the sort of disparate impacts we describe here; to address such outcomes we also need to trace them back to organizational actions, and inactions. What are the organizational assumptions, constraints, practices that predictably give rise to heterogenous effects by race? Since those characteristics are often too deeply embedded in the organization to be obvious and apparent to its users, it requires a toolset to diagnose and address those problems.

While our examples and motivation are tied to a US setting, the issues of racialized burdens are more broadly applicable. To be sure, few countries have the history of the United States that forms the basis for our examples, and the peculiar tensions of an administrative system that arose in the context of slavery, Jim Crow laws, massive immigration and ensuing hostility. But neither are other countries exempt. Examining how racialized public organizations historically give rise to the unequal distribution of burdens seems especially salient in countries with a colonial history, or different forms of caste systems. Understanding these dynamics demands a nuanced investigation of context and history of many aspects of the world that are rarely present in public administration journals. Similarly, the influx of Middle Eastern and African immigrants into Europe poses a contemporary question for public organizations that 
were formed by and to serve a predominantly white and Christian population. Regardless of the setting and particular dynamics, a disciplined search for racialized burdens allows us to uncover and compare aspects of the administrative state usually kept hidden. 


\section{References}

Alexander, Jennifer, and Camilla Stivers. 2010. An ethic of race for public administration. Administrative Theory \& Praxis 32(4): 578-597.

Alexander, Jennifer, and Camilla Stivers. 2020. Racial bias: A buried cornerstone of the administrative state. Administration \& Society 52(10): 1470-1490.

Anderson, Carol. 2018. One person, no vote: How voter suppression is destroying our democracy. Bloomsbury Publishing USA.

Aneja, Abhay and Guo Xu. 2020. The costs of employment segregation: Evidence from the federal government under Wilson. NBER Working Paper no. 27798.

Atkeson, Lonna, Lisa Bryant, Thad Hall, Kyle Saunders, and Michael Alvarez. 2010. A new barrier to participation: Heterogeneous application of voter identification policies. Electoral Studies 29(1): 66-73.

Barnes, Carolyn Y. 2021. It Takes a While to Get Used to": The Costs of Redeeming Public Benefits. Journal of Public Administration Research and Theory 31(2): 295-310.

Barnes, Carolyn, and Julia Henly. 2018. They are underpaid and understaffed: How clients interpret encounters with street-level bureaucrats. Journal of Public Administration Research and Theory 28(2): 165-181.

Baekgaard, Martin, Mette Kjærgaard Thomsen and Donald Moynihan. 2021. Why do policymakers support administrative burdens? The roles of deservingness, political ideology and personal experience. Journal of Public Administration Research and Theory 31(1): 184-200.

Barofsky, Jeremy, Ariadna Vargas, Dinardo Rodriguez, and Anthony Barrows. 2020. Spreading fear: The announcement of the public charge rule reduced enrollment in child safety-net programs. Health Affairs 39(10): 1752-61.

Barreto, Matt, Stephen Nuno, and Gabriel Sanchez. 2009. The disproportionate impact of voterID requirements on the electorate: new evidence from Indiana. PS: Political Science and Politics 42(1): 111-116.

Bell, Elizabeth, Ani Ter Mkrtchyan, Wesley Wehde and Kylie Smith. 2021. Just or unjust? How ideological beliefs shape street-level bureaucrats' perceptions of administrative burden. Public Administration Review 81(4): 610-624.

Berman, Ari. 2015. Give Us the Ballot: The Modern Struggle for Voting Rights in America. London: Macmillan. 
Bonilla-Silva, Eduardo. 2010. Racism without racists: Color-blind racism and the persistence of racial inequality in the United States. Lanham, MD: Rowman \& Littlefield.

Bracey, Glenn. 2015. Toward a critical race theory of state. Critical Sociology 41(3): 553-72.

Brennan Center for Justice. 2019. New voting restrictions in America. https://www.brennancenter.org/our-work/research-reports/new-voting-restrictionsamerica

Brown, Hana. 2013. Race, legality, and the social policy consequences of anti-immigration mobilization. American Sociological Review 78(2): 290-314.

Brown, Hana. 2020. Who Is an Indian child? Institutional context, tribal sovereignty, and racemaking in fragmented states. American Sociological Review 85(5): 776-805.

Chen, M. Keith, Kareem Haggag, Devin Pope and Ryne Rohla. 2020. Racial Disparities in Voting Wait Time: Evidence from Smart Phone Data. Review of Economics and Statistics. https://doi.org/10.1162/rest_a_01012

Cohen, Elizabeth. 2018. The Political Value of Time. Princeton, NJ: Princeton University Press.

Christensen, Julian, Lene Aarøe, Martin Baekgaard, Pamela Herd, and Donald P. Moynihan. 2020. Human capital and administrative burden: The role of cognitive resources in citizen-state interactions. Public Administration Review 80(1): 127-36.

Cottom, Tressie McMillam. 2019. Thick. New York: New Press.

Edwards, Frank, Sara Wakefield, Kieran Healy and Christopher Wideman. 2021. Contact with Child Protective Services is pervasive but unequally distributed by race and ethnicity in large US counties. Proceedings of the National Academy of Science 118(30) e2106272118; https://doi.org/10.1073/pnas.2106272118

Epp, Charles, Steven Maynard-Moody, and Donald Haider-Markel. 2014. Pulled over: How Police Stops Define Race and Citizenship. Chicago, IL: University of Chicago Press.

Gilens, Martin. 2009. Why Americans Hate Welfare. Chicago, IL: University of Chicago Press.

Gooden, Susan. 2014. Race and Social Equity: A Nervous Area of Government. Armonk, NY: M.E. Sharpe.

Gordon, Linda. 1991. Black and white visions of welfare: Women's welfare activism, 18901945. The Journal of American History 78(2): 559-590.

Hahn, Heather, Laudan Aron, Cary Lou, Eleanor Pratt, and Adaeze Okoli. 2017. Why does cash welfare depend on where you live? Urban Institute report. 
Hainmueller, Jens, Duncan Lawrence, Justin Gest, Michael Hotard, Rey Koslowski, and David Laitin. 2018. A randomized controlled design reveals barriers to citizenship for lowincome immigrants. Proceedings of the National Academy of Sciences 115(5): 939-44.

Haney Lopez, Ian. 1997. White by law: The legal construction of race. New York, NY: NYU Press.

Meyer, Madonna Harrington. 1996. Making claims as workers or wives: The distribution of social security benefits. American Sociological Review 61(3): 449-465.

Harris, Cheryl. 1993. Whiteness as Property. Harvard Law Review 106(8): 1707-91.

Heinrich, Carolyn. 2016. The bite of administrative burden. Journal of Public Administration Research and Theory 26(3): 403-20.

Heinrich, Carolyn. 2018. "A thousand petty fortresses": Administrative burden in U.S. immigration policies and its consequences. Journal of Policy Analysis and Management 37(2): 211-39.

Herd, Pamela. 2005. Reforming a breadwinner welfare state: Gender, race, class, and Social Security reform. Social Forces 83(4): 1365-1393.

Herd, Pamela, and Donald Moynihan. 2018. Administrative burden: Policymaking by other means. New York, NY: Russell Sage Foundation.

Institute on Taxation and Economic Policy. 2021. President Biden's Proposed Child Tax Credit Expansion Would Reduce Poverty, Address Racial Disparities https://itep.org/child-taxcredit-enhancements-under-the-american-rescue-plan/

Jenkins, Jade Marcus, and Tutrang Nguyen. 2021. Keeping kids in care: Reducing administrative burden in state Child Care Development Fund policy. Journal of Public Administration Research and Theory. https://doi.org/10.1093/jopart/muab020

Jilke, Sebastian, Wouter Van Dooren, and Sabine Rys. 2018. Discrimination and administrative burden in public service markets: Does a public-private difference exist? Journal of Public Administration Research and Theory 28(3): 423-39.

Jung, Moon-Kie, and Yaejoon Kwon. 2013. Theorizing the US racial state: Sociology since racial formation. Sociology Compass 7(11): 927-40.

Liang, Jiaqi. 2016. The shadow of the politics of deservedness? The implications of groupcentric policy context for environmental policy implementation inequalities in the United States. Journal of Public Administration Research and Theory 26(3): 552-570. 
Kaiser Family Foundation. 2020. Changes in Coverage by Race and Ethnicity. https://www.kff.org/racial-equity-and-health-policy/issue-brief/changes-in-healthcoverage-by-race-and-ethnicity-since-the-aca-2010-2018/

Keele, Luke, William Cubbison, and Ismail White. 2021. Suppressing Black Votes: A Historical Case Study of Voting Restrictions in Louisiana. American Political Science Review 115(2): 694-700.

Katznelson, Ira. 2005. When affirmative action was white: An untold history of racial inequality in twentieth-century America. New York: W.W. Norton.

Klain, Hannah, Kevin Morris, Max Feldman, and Rebecca Ayala. 2020. Waiting to Vote: Racial Disparities in Election Day Experiences. Brennan Center for Justice report.

Kohler-Hausmann, Julilly. 2007. The crime of survival: Fraud prosecutions, community surveillance, and the original "welfare queen." Journal of Social History: 329-354.

Law, Anne. 2014. Lunatics, Idiots, Paupers and Negro Seamen-Immigration Federalism and the Early American State. Studies in American Political Development. 28(2): 107-128.

Lee, Erika. 2002. The Chinese exclusion example: Race, immigration, and American gatekeeping, 1882-1924. Journal of American Ethnic History: 36-62.

Leonard, Thomas. 2017. Illiberal reformers: race, eugenics, and American economics in the Progressive Era. Princeton University Press.

Masood, Ayesha and Muhammad Azfar Nisar. 2021. Administrative capital and citizens' responses to administrative burden. Journal of Public Administration Research and Theory. 31(1): 55-72.

Marshall, T.H. 1964. Class, citizenship and social development. New York, NY: Doubleday.

Meier, Kenneth. 2019. Theoretical frontiers in representative bureaucracy: New directions for research. Perspectives on Public Management and Governance 2(1): 39-56.

Mettler, Suzanne, 1998. Dividing citizens: Gender and Federalism in New Deal Public Policy. Cornell University Press.

Mettler, Suzanne. 2011. The Submerged State: How Invisible Government Policies Undermine American Democracy. University of Chicago Press.

Meyer, John and Brian Rowan. 1977. Institutionalized organizations: Formal structure as myth and ceremony. American Journal of Sociology 83(2): 340-63. 
Michener, Jamila. 2018. Fragmented Democracy: Medicaid, Federalism and Unequal Politics. New York: Cambridge University Press.

Michener, Jamila 2019. Policy Feedback in a Racialized Polity. Policy Studies Journal. 47(2): 423-450

Mills, Charles. 2014. White time. Du Bois Review 11(1): 27.

Mink, Gwendolyn. 1998. Welfare's End. Cornell University Press.

Mower, Lawrence and Langston Taylor. 2020. In Florida, the gutting of a landmark law leaves few felons likely to vote. https://www.propublica.org/article/in-florida-the-gutting-of-alandmark-law-leaves-few-felons-likely-to-vote

Moynihan, Donald, and Joe Soss. 2014. Policy feedback and the politics of administration. Public Administration Review 74(3): 320-332.

Moynihan, Donald, Pamela Herd and Julie Gerinza. In Press. “Kafka’s Bureaucracy: Immigration Administrative Burdens in the Trump Era." Perspectives on Public Management and Governance. 10.1093/ppmgov/gvab025

Moynihan, Donald, Pamela Herd and Hope Harvey. 2014. Administrative burden: Learning, psychological, and compliance costs in citizen-state interactions. Journal of Public Administration Research and Theory 25(1): 43-69.

Ngai, Mae. 1999. The architecture of race in American immigration law: A reexamination of the Immigration Act of 1924. The Journal of American History 86(1): 67-92.

Nisar, Muhammed. 2018. Children of a lesser god: Administrative burden and social equity in citizen-state interactions. Journal of Public Administration Research and Theory 28(1): 104-19.

Oliver, Melvin, and Thomas Shapiro. 2006. Black Wealth, White Wealth: A New Perspective on Racial Inequality. Taylor \& Francis.

Olsen, Asmus Leth, Jonas Høgh Jeppesen, and Donald P. Moynihan. 2020. The Unequal Distribution of Opportunity: A National Audit Study of Bureaucratic Discrimination in Primary School Access. American Journal of Political Science. https://doi.org/10.1111/ajps.12584

Omi, Michael, and Howard Winant. 2014. Racial Formation in the United States. New York: Routledge.

O' Toole, Molly. 2019. Asylum officers rebel against Trump policies they say are immoral and illegal. The Los Angeles Times. https://www.latimes.com/politics/story/2019-1115/asylum-officers-revolt-against-trump-policies-they-say-are-immoral-illegal 
Phillips, Anthony Jamal, and Natalie Deckard. 2016. Felon disenfranchisement laws and the feedback loop of political exclusion: The case of Florida. Journal of African American Studies 2(1): 1-18.

Peeters, Rik. 2020. The political economy of administrative burdens: A theoretical framework for analyzing the organizational origins of administrative burdens. Administration \& Society 52(4): 566-92.

Posselt, Julie. 2020. Equity in Science: Representation, Culture, and the Dynamics of Change in Graduate Education. Palo Alto, CA: Stanford University Press.

Pratt, Eleanor and Heather Hahn. 2021. What Happens When People Face Unfair Treatment or Judgement When Applying for Social Assistance or Social Services. Urban Institute report.

Quadagno, Jill. 1994. The Color of Welfare: How Racism Undermined the War on Poverty. Oxford University Press.

Ray, Victor. 2019a. A theory of racialized organizations. American Sociological Review 84(1): 26-53.

Ray, Victor. 2019b. Why so Many Organizations Stay White. Harvard Business Review, November 19, 2019.

Ray, Victor, and Danielle Purifoy. 2019. The colorblind organization. In Wooten, M.E. (ed.), Race, organizations, and the organizing process 131-150. Bingley, UK: Emerald Group.

Reskin, Barbara. 2003. Including mechanisms in our models of ascriptive inequality. American Sociological Review. 68(1): 1-21.

Roberts, Alasdair. 2020a. Bridging levels of public administration: How macro shapes meso and micro. Administration \& Society 52(4): 631-656.

Roberts, Alasdair. 2020b. Bearing the white man's burden: American empire and the origin of public administration. Perspectives on Public Management and Governance 3(3): 185196.

Schram, Sanford, Joe Soss, Richard Fording, and Linda Houser. 2009. Deciding to discipline: Race, choice, and punishment at the frontlines of welfare reform. American Sociological Review 74(3): 398-422.

Seamster, Louise, and Victor Ray. 2018. Against teleology in the study of race: Toward the abolition of the progress paradigm. Sociological Theory 36(4): 315-342. 
Shaffer, Donald. 2000. "I Do Not Suppose That Uncle Sam Looks at the Skin": African Americans and the Civil War Pension System, 1865-1934. Civil War History 46(2):132147.

Skocpol, Theda. 1995. Protecting Soldiers and Mothers. New York: Belknap Press.

Soss, Joe, Sanford Schram, Thomas Vartanian, and Erin O' Brien. 2001. Setting the terms of relief: Explaining state policy choices in the devolution revolution. American Journal of Political Science. 45(2): 378-395.

Soss, Joe, Richard C. Fording, and Sanford F. Schram. 2011. Disciplining the poor: Neoliberal paternalism and the persistent power of race. University of Chicago Press.

Soss, Joe, and Vesla Weaver. 2017. Police are our government: Politics, political science, and the policing of race-class subjugated communities. Annual Review of Political Science 20: 565-591.

Stein, Robert, Christopher Mann, Charles Stewart, Zachary Birenbaum, Anson Fung. 2020. Waiting to vote in the 2016 presidential election. Political Research Quarterly 73(2): 439-453.

Tomaskovic-Devey, Donald, and Dustin Avent-Holt. 2019. Relational Inequalities: An Organizational Approach. Oxford: Oxford University Press.

Uggen, Chris, Ryan Larson, Sarah Shannon and Arleth Pulido-Nava. 2020. Locked Out 2020: Estimates of People Denied Voting Rights Due to a Felony Conviction. The Sentencing Project.

Watkins-Hayes, Celeste. 2011. Race, respect, and red tape: Inside the black box of racially representative bureaucracies. Journal of Public Administration Research and Theory 21 (2): i233-i251.

White, Ariel, Noah Nathan, and Julie Faller. 2015. What do I need to vote? Bureaucratic discretion and discrimination by local election officials. American Political Science Review 109(1): 129-142.

Wooten, Melissa E. 2006. "Soapbox : Editorial Essays: Race and Strategic Organization.” Strategic Organization 4(2):191-99.

Wooten, Melissa, and Lucius Couloute. 2017. The Production of Racial Inequality within and among Organizations: Organizational Inequality. Sociology Compass 11(1):e12446.

Whitman, James. 2017. Hitler's American model: The United States and the making of Nazi race law. Princeton University Press. 